\title{
Managerial Ability and The Quality of Firms' Information Environment
}

\author{
Bok Baik, Paul A. Brockman, David B. Farber, Sam (Sunghan) Lee
}

\section{Introduction}

In this study, we examine the relation between managerial ability and the quality of firms' information environment. A firm's information environment not only includes financial reporting, it also includes market intermediaries, such as analysts (Bushman et al. 2004). ${ }^{1}$ An emerging stream of research has identified the role of managerial ability in enhancing financial reporting quality. Conceptually, higher ability managers have a better understanding of their firms' business (Mahoney 1995; Coff 1997; Demerjian et al. 2012) and use this knowledge to inform investors more effectively (Francis et al. 2008; Malmendier and Tate 2009; Baik et al. 2011; Demerjian et al. 2013; Baik et al. 2017). However, missing from the literature is evidence about the impact of managerial ability on a comprehensive measure of firms' information environment. Our study seeks to fill this void.

There are plausible competing arguments and mixed results from prior research on the relation between managerial ability and financial reporting disclosure. Prior research argues and shows that equity-based compensation incentivizes high ability managers to improve financial reporting quality, suggesting a positive relation between managerial ability and the quality of firms' forecasts, as well as the market response to these forecasts (Trueman 1986; Milbourn

\footnotetext{
1 Among many information channels, Beyer, Cohen, Lys, and Walther (2010) argue that private information acquisition through analysts is the second most important source of accounting-based information. Beyer et al. (2010) decompose firms' quarterly stock return variance to show the relative contribution of information sources. Management forecast and earnings pre-announcement (voluntary disclosures) explain 66\% of accounting-based information and analyst forecasts explain $22 \%$ of accounting-based information.
}

This is the author's manuscript of the article published in final edited form as: 
2003). ${ }^{2}$ Baik et al. (2011) show that managerial ability is positively related to the frequency and accuracy of management earnings forecasts, as well as the market response to these forecasts, further supporting a positive relation between managerial ability and the quality of firms' information environment. By contrast, extant research supports the notion that higher ability managers can impair firms' information environment through opaque financial disclosures (Hermalin and Weisbach 1998; Bebchuk et al. 2002). ${ }^{3}$ Demerjian et al. (2013) provide somewhat mixed evidence about the relation between managerial ability and accruals quality; they show that the data envelope analysis (DEA) measure of managerial ability is positively associated with accruals quality, but that the media citations proxy for managerial ability is negatively associated with accruals quality.

Previous studies showing a relation between managerial ability and financial disclosures only examine specific financial reporting channels (e.g., management forecasts) instead of using measures that capture overall disclosure quality. Dechow et al. (2010) highlight that there are many aspects of financial reporting that comprise firms' information environment but these different aspects of financial reporting are not all positively related to each other. For example, Dechow et al. (2010) describe inverse associations between income smoothing, accruals, TLR, and ERCs. Prior research on disclosures (Francis et al. 1997; Frankel et al. 1999; Bushee et al. 2003; Brown et al. 2015) also documents that there is significant cross-sectional variation in the individual channels chosen to provide financial information. Tasker (1998) finds a negative association between the informativeness of firms' financial reporting and the likelihood of conference calls.

\footnotetext{
${ }^{2}$ The positive relation between equity incentives and the quality of firms' information environment does not preclude the possibility that equity incentives motivate low ability managers. We discuss this issue in more detail on pages 8-9.

${ }^{3}$ Relatedly, a Wall Street Journal article indicates that even after new compensation reporting rules were implemented in 2006, companies rarely tabulated all of their post-retirement obligations to top executives (Schultz and McGinty 2009).
} 
Thus, the use of specific disclosure channels in extant research further clouds our understanding of the relation between managerial ability and the quality of firms' information environment. In sum, the relation between managerial ability and firms' overall information environment remains an unresolved question.

Recognizing various channels and aspects of financial disclosures, Hilary (2006) highlights two significant empirical issues when using specific disclosure channels: (i) a potential spurious conclusion due to the fact that various disclosure channels may be substitutes or complements; and (ii) a potential endogeneity problem due to the challenges of finding adequate instruments. In the spirit of Hilary (2006), we use a composite measure to capture the quality of firms' information environment, as reflected in analyst following, analyst forecast accuracy, bid-ask spread, and trading volume. These measures enable us to capture both formal and informal communication channels as well as public information flows that are difficult to measure. ${ }^{4}$ We find additional support for our measures in Hilary (2006), who proposes that using summary measures for overall disclosure, such as bid-ask spread and trading volume, can overcome empirical issues associated with the use of individual disclosure channels. ${ }^{5}$ We therefore believe that this approach will provide more complete and convincing evidence on the relation between managerial ability and the quality of firms' information environment.

We follow prior research (Anderson, Duru, and Reeb 2009; Chen, Cheng, and Wang 2011) and create a composite measure of firms' information environment (InfoEnv_Index) based on four proxies commonly used in accounting and finance research to capture information environment quality: (i) bid-ask spread; (ii) trading volume; (iii) analyst following; and (iv) analyst forecast

\footnotetext{
${ }^{4}$ Our tests explicitly control for individual disclosure channels identified in prior research (i.e., management forecast likelihood, accrual quality, and income smoothing).

${ }^{5}$ Hilary (2006) tests how labor unions impact overall disclosure, as reflected in measures similar to those we use in our study.
} 
errors. We use DEA Score as our primary measure of managerial ability, following Demerjian et al. (2012), who use data envelope analysis (DEA) to create a measure of manager-specific efficiency (i.e., ability). DEA has been utilized in other settings, such as research investigating the relation between managerial ability and management earnings forecasts (Baik et al. 2011), earnings quality (Demerjian et al. 2013), and income smoothing (Baik et al. 2017). Because managerial ability is multi-dimensional and therefore difficult to measure, we supplement our main analyses using two alternative measures of managerial ability. Our first alternative measure of managerial ability is based on the number of press citations for a CEO over a prior five-year period. This measure is consistent with that used in Milbourn (2003), Rajgopal et al. (2006), and Francis et al. (2008). The intuition behind the press citation measure is that the press tends to cite more talented CEOs. ${ }^{6}$ For our second alternative measure of managerial ability, we follow Rajgopal et al. (2006) and use industry-adjusted return on assets during the prior three years of a particular CEO's tenure.

Using a large sample of observations for the period 1993-2010, we find that firms with higher ability managers have a higher quality information environment, even after controlling for variables known to be associated with information environment such as size, risk, return on assets, firm age, growth, and leverage. Importantly, our results are incremental to the inclusion in our regression models of individual measures of information quality documented in extant research, such as management forecast likelihood (Baik et al. 2011), accruals quality (Demerjian et al. 2013), and income smoothing (Baik et al. 2017). These results suggest that less formal disclosures from high ability managers impact firms' information environment, thereby reinforcing our motivation for using measures of overall disclosure. As highlighted in Francis et

\footnotetext{
${ }^{6}$ We perform additional analyses later in the paper to confirm that most press releases (95\%) are either neutral or positive in content, which is consistent with Milbourn (2003), Francis et al. (2008), and Baik et al. (2011).
} 
al. (2008), it is possible that high ability managers self-select into firms with better information environments, thereby increasing the potential that endogeneity in the form of self-selection drives our results. To rule out this possibility, we follow Francis et al. (2008) and conduct a simultaneous equations analysis. Results from this analysis suggest that self-selection bias does not drive our results.

We discussed earlier that high ability managers have equity incentives to improve their firms' information environment. If managers' equity incentives drive their disclosure choices, then we expect to observe a more pronounced positive relation between managerial ability and the quality of firms' information environment when managers' equity incentives are greater. We report that this is indeed the case. That is, we show that the positive relation between managerial ability and the quality of firms' information environment increases to a greater extent when managers own more shares of their firms' stock and when they have higher levels of stock options.

Our results suggest that greater equity incentives lead managers of higher ability to create a better information environment for the firm. To provide confirmatory evidence, we test for the effects of corporate governance on the relationship between equity incentives, managerial ability and the information environment. We find that weak monitoring amplifies the positive relation between managerial ability and information environment, thus providing further support for the hypothesis that equity incentives motivate managers of high ability to maintain a better information environment. Thus, firms with weak governance benefit more from managers of high ability with regard to information quality.

We make several important contributions to the literature. Our study helps to unify prior research on the impact of managerial ability on financial disclosures. Prior research provides 
evidence about specific disclosure channels and does not address the impact of managerial ability on firms' broader information environment. Additionally, evidence about the relation between managerial ability and accruals quality is somewhat mixed. Thus, extant research does not provide conclusive and complete evidence about the relation between managerial ability and financial reporting quality, an important aspect of firms' broader information environment. Given that analysts and other market intermediaries reflect the net consequences of multiple dimensions of corporate disclosure (e.g., voluntary disclosures, mandatory disclosures, and SEC enforcement actions), our use of a composite measure for disclosure allows us to draw stronger inferences about the relation between managerial ability and firms' overall corporate disclosure.

Our study also extends the literature that examines determinants of the quality of firms' information environment (e.g., Karamanou and Vafeas 2005; Anderson et al. 2009; Baik et al. 2010; Drake et al. 2015). In particular, our study complements Baik et al. (2010), who report a negative relation between managerial ownership and analyst following. Our findings suggest that higher managerial ownership coupled with higher ability managers can improve information environments. More broadly, our study complements the literature on the relation between a manager's personal characteristics and important corporate decisions and outcomes. In particular, this literature has documented that a manager's personal characteristics are related to corporate policies involving investing and financing decisions (Bertrand and Schoar 2003), executive compensation (Milbourn 2003; Rajgopal et al. 2006), voluntary disclosure (Bamber et al. 2010), and market returns and firm value (Demerjian et al. 2012). We add to this line of research by demonstrating that managerial ability helps to explain cross-sectional variation in the quality of firms' information environment.

Our results have practical implications for investors and boards of directors. Because the 
quality of firms' information environment impacts the cost of capital (e.g., Easley and O'Hara 2004), our study has important implications for investors' portfolio choices. Results from our study should also be useful to boards in their deliberations about hiring and firing managers. In their hiring decisions, for example, boards can expect that candidate managers with high ability will also be more transparent and communicative with outside investors.

Several caveats are in order. First, although we adopt our measures of managerial ability from previous studies, we acknowledge that it is difficult to identify an all-encompassing proxy for managerial ability because it is not readily observable. Our empirical evidence should therefore be interpreted with some caution. Second, our study has a potential sample selection bias. To construct our managerial ability measures, we use data from ExecuComp. Because ExecuComp focuses on larger firms, our inferences might not generalize to smaller firms.

Our paper proceeds as follows. In Section 2, we discuss literature relevant to our study and develop our main empirical prediction. Section 3 describes the sample and data. Section 4 provides the research design and section 5 contains our main empirical results. We present robustness tests in section 6 and additional tests in section 7. Section 8 summarizes and concludes the study.

\section{Literature Review and Hypothesis Development}

A growing literature involving scholars in accounting, economics, and finance examines the impact of managerial characteristics on corporate decisions and outcomes, such as investing and financing (Bertrand and Schoar 2003), executive compensation (Milbourn 2003), earnings quality (Demerjian et al. 2013), management earnings forecasts (Baik et al. 2011; Bamber et al. 2010), and income smoothing (Baik et al. 2017). We complement and extend this literature by examining the relation between managerial ability and the quality of firms' information environment. 
There are plausible competing arguments for the direction of the relation between managerial ability and the quality of firms' information environment. One perspective on this relation is that equity-based compensation provides high ability managers with incentives to enhance financial reporting, leading to better information environment. Milbourn (2003) reports that managerial ability is positively associated with (equity) pay-performance sensitivity, which implies that high ability managers receive a substantial amount of equity-based compensation. Trueman (1986) theorizes that because the market values information about changes in firms' underlying economics, high ability managers' equity-based compensation incentivizes them to inform the market about such changes via voluntary earnings forecasts. Relatedly, Baik et al. (2011) report that managerial ability is positively related to the likelihood, accuracy, and value relevance of voluntary management earnings forecasts. Other recent studies document evidence consistent with high ability managers improving their firms' information environment. Demerjian et al. (2013) show that earnings quality increases in managerial ability, while Baik et al. (2017) report that firms with high ability managers have more predictable earnings.

While equity incentives potentially motivate low ability managers to improve their firms' information environment, it may not be in their interests to do so. Trueman (1986) argues that equity incentives motivate high ability managers to provide voluntary management earnings forecasts because doing so will increase their firms' stock price and consequently lead to higher wealth for managers. A critical assumption of Trueman's (1986) argument is that because of their superior skill, high ability managers face a different cost benefit trade-off from disclosure and lower ability managers will not follow the same strategy as high ability managers. This argument also applies to other individual disclosure channels, such as accrual quality and smoothing, and more generally to overall disclosure. 
A different perspective is that high ability managers increase their payoffs through opaque disclosures. Previous studies also argue that entrenched managers could extract a greater informational rent through the use opaque financial reporting (Bebchuk et al. 2002; Bebchuk and Fried 2004; Kalyta and Magnan 2008). Other studies suggest that strong governance provides monitoring over managers and encourages them to improve their firms' information environment (Dechow, Sloan, and Sweeney 1996; Beasley 1996; Klein 2002; Healy, Hutton, and Palepu 1999; Bushee and Noe 2000) even though it may not be in the manager's self-interest. Even after the SEC implemented new rules in 2006 that standardized executive compensation disclosures, firms continued to provide vague or incomplete disclosures about executive pensions (Schultz and McGinty 2009). It is also possible that low ability managers could earn greater informational rents through obscure financial reporting, leading to a weaker information environment.

As we discussed earlier, the use of specific disclosure channels in extant research raises significant empirical issues that do not allow us to draw strong conclusions about the impact of managerial ability on firms' information environment. Thus, based on theory, conflicting empirical evidence, as well as empirical issues associated with using specific disclosure channels, the direction of the relation between managerial ability and firms' information environment is an open empirical question. The preceding arguments lead to the following hypothesis, stated in the null form:

Hypothesis: There is no relation between managerial ability and the quality of firms' information environment.

\section{Sample and Data}

We identify an initial sample of 18,258 firm-year observations from the intersection of 
ExecuComp/IBES/CRSP databases for the years 1993-2010 to construct managerial ability and information environment proxies. ${ }^{7}$ We lose 1,738 firm-year observations after merging this data set with the First Call Company Issued Guidance (CIG), which is required to construct management forecast issuance likelihood. Merging our sample with Compustat (for control variables) results in the loss of another 1,313 firm-year observations. The final sample consists of 15,207 firm-year observations.

We adopt a proxy for managerial ability from Demerjian et al. (2012), who use data envelope analysis (DEA) to derive a measure of management-specific ability. ${ }^{8}$ This measure of managerial efficiency can be thought of as a performance-based measure of innate managerial ability. In validity checks of their measure, Demerjian et al. (2012) find that it is positively related to five alternative measures of managerial ability used in prior research: historical industry-adjusted stock returns, historical industry-adjusted return-on assets (ROA), CEO compensation, CEO tenure, and media mentions. This gives us added comfort that the DEA measure is capturing a significant dimension of managerial ability.

It is difficult to measure directly firms' information environment. This difficulty arises in part from the multi-dimensional nature of this construct. We attempt to capture the multidimensional nature of firms' information environment by compiling indexes of firms' information environment from multiple measures employed in prior research (Diamond and Verrecchia 1991; Leuz and Verrecchia 2000; Botosan et al. 2004; Anderson et al. 2009). We use analyst following as our first proxy for information environment. We measure analyst following as the natural logarithm of the number of analysts following each firm. Analysts serve as an important

\footnotetext{
${ }^{7}$ The sample period ends in 2010 because First Call stopped providing management earnings forecasts after 2010.

${ }^{8}$ We obtain data for the DEA-based measure of managerial ability from Peter Demerjian's web site. For robustness, we use press citations and industry-adjusted ROA as alternative measures of managerial ability (Rajgopal et al. 2006; Francis et al. 2008; Baik et al. 2011).
} 
intermediary by conveying information from corporations to investors. Higher analyst coverage reflects a more sophisticated information environment and more market scrutiny over corporate disclosure. Analyst forecast accuracy is our second proxy for information environment. Analyst forecast accuracy reflects the availability of firm information in the capital market. We calculate analyst forecast error as the square of the difference between the mean analysts' earnings forecast and actual firm earnings divided by the firm's stock price, following Anderson et al. (2009).

Our third proxy for information environment is trading volume. Prior research shows that trading volume captures the quality of information environment in market trades (Leuz and Verrecchia 2000; Lo et al. 2004). We measure trading volume as the average daily dollar trading volume (from CRSP) during the fiscal year. We employ bid-ask spread as the fourth proxy for information environment. Bid-ask spread is a widely used proxy for information asymmetry among investors (Diamond and Verrecchia 1991). We measure bid-ask spread using annual mean of daily bid-ask spread calculated by ask price minus bid price divided by the average of bid and ask prices from CRSP.

We follow the procedure in Anderson et al. (2009) to create a composite index of information environment (InfoEnv_Index) based on the four information environment proxies. For each firm, we rank the four information environment proxies (trading volume, bid-ask spread, analyst following, and analyst forecast errors) into deciles, in which firms with the most (least) information environment have a value of 10 (1). We then sum the four rankings and divide them by 40 (total possible points), yielding a measure that ranges between 1 (highest information environment quality) and 0.1 (lowest information environment quality). To alleviate the concern of artificially assigning equal weights among multiple proxies to construct a composite index, we also run factor analyses on the information environment proxies and obtain qualitatively similar 
results.

\section{Research Design}

To test the relation between information environment and managerial ability, we estimate the following OLS model:

InfoEnv_Index $=\alpha+\beta_{1}$ Ability $+\beta_{2}$ Size $+\beta_{3}$ Risk $+\beta_{4}$ Performance $+\beta_{5}$ Firm Age $+\beta 6$ Growth $+\beta 7$ Leverage $+\beta 8$ Disclose $+\beta 9$ Accrual Quality $+\beta_{10}$ Smoothing $+\varepsilon$,

where InfoEnv_Index is a composite index of information environment, as described above. Recall that the InfoEnv_Index ranges between 1 (highest information environment quality) and 0.1 (lowest information environment quality). Ability is DEA Score based on the measure from Demerjian et al. (2012).

We also include control variables in our regression models that prior research has linked to information environment (Bhushan 1989; O'Brien and Bhushan 1990; Lang and Lundholm 1993; Lang and Lundholm 1996; Barth et al. 2001; Lim 2001; Karamanou and Vafeas 2005; Frankel et al. 2006; Anderson et al. 2009). We based the predicted sign (in brackets) for each control variable on prior research. In cases where prior research provides ambiguous results, we indicate that using a question mark. Size is measured as the natural log of total assets $(+)$. Risk is the standard deviation of monthly stock returns for the previous 36 months (-). Performance is return on assets, measured as income before extraordinary items divided by average total assets from the prior year $(+)$. Firm Age is measured as the number of years since the firm first appeared on CRSP (?). Growth is firm growth opportunities, measured as research and development expenses divided by total assets (R\&D Expenses / total assets) (?). Leverage is the firm's debt ratio, measured as total long-term debt divided by total assets (-). Disclose is a dummy variable 
of management forecast likelihood set equal to 1 if there is an annual management earnings forecast in year t, 0 otherwise, following Baik et al. (2011) (+). Accrual Quality is measured using a modified Dechow and Dichev (2002) accrual model, following Demerjian et al. (2013) (+). For easier interpretation, Accrual Quality is multiplied by negative one to indicate that a high number indicates high accrual quality. Smoothing is income smoothing measured by the standard deviation of earnings divided by the standard deviation of cash flows from operations, where earnings and cash flows are scaled by lagged total assets following Baik et al. (2017) (+). For easier interpretation, Smoothing is multiplied by negative one, such that a high number indicates high smoothing. All analyses control for firm and year fixed effects.

\section{Descriptive Statistics, Correlations, and Empirical Results}

\subsection{Descriptive Statistics}

We provide descriptive statistics for our sample in Table 1. InfoEnv_Index has a mean (median) of 0.567 (0.575). We also report descriptive statistics for each component of InfoEnv_Index. Analyst following has a mean (median) of 11.845 (10.000), analyst forecast error has a mean (median) of 0.005 (0.001), trading volume has a mean (median) of 47.66411 .427 ) million dollars, and Bid-Ask Spread has a mean (median) of 0.008 (0.003). The sample firms are large and profitable, with mean (median) Size (total assets) of $\$ 4.80$ (\$1.26) billion and mean (median) Performance (return on assets) of 5.0\% (5.8\%). The mean (median) of DEA Score is $0.018(0.007)$. The mean (median) Risk (standard deviation of monthly returns) for our sample is $0.13(0.11)$. The mean (median) firm age is $22.5(16.0)$ years, suggesting that our sample consists of mature firms. Mean (median) R\&D Expenses (Growth) is $4.1 \%(0.7 \%)$ of total assets and mean (median) leverage is $17.8 \%(15.6 \%)$ of total assets. On average, $39.7 \%$ of sample firms issue management forecasts for the year. Most of the variables are fairly well symmetrically distributed, 
except for Size, both of which have means well in excess of their medians. We account for this skewness by using decile rankings in the regression analyses.

\section{[Insert Table 1 here]}

\subsection{Pearson Correlations}

In Table 2, we provide Pearson correlations between the variables used in our regression analyses. InfoEnv_Index has a significant positive correlation with DEA Score. Consistent with previous managerial ability studies, management forecast likelihood and smoothing are positively associated with DEA Score. Furthermore, InfoEnv_Index is positively associated with management forecast likelihood, accrual quality, and smoothing. These correlations indicate the need of controlling management forecast likelihood, accrual quality, and smoothing in our regression model as we do in model (1). We find similar results using Spearman correlations (untabulated). Although none of the correlations appears large enough to cause collinearity concerns, we nevertheless formally test for collinearity in our regression analyses. ${ }^{9}$

\section{[Insert Table 2 here]}

\subsection{Regression Results for Managerial Ability and Information Environment}

We provide regression results for the relation between information environment and managerial ability in Table 3. After controlling for firm characteristics that have been shown to affect firms' information environment, we report a significant coefficient of $0.056(\mathrm{p}<0.01)$ on DEA Score, which supports our hypothesis of a positive association between managerial ability and firms' information environment. These results suggest that high ability managers provide

\footnotetext{
${ }^{9}$ VIFs in the regressions do not exceed 2 (untabulated), suggesting that collinearity problems do not likely impact our results.
} 
information that enhances firms' overall information environment incremental to that provided by individual disclosure channels, such as management forecasts, accrual quality, and smoothing. Our results thus support the use of summary disclosure measures to capture overall disclosure attributable to high ability managers. Results for the control variables are consistent with those found in prior research. We next assess the economic significance of these results. Moving from the third decile to the eighth decile of DEA Score increases the InfoEnv_Index by $13.7 \%$ of the standard deviation of InfoEnv_Index. Thus, the results in Table 3 are economically, as well as statistically, significant.

\section{[Insert Table 3 here]}

For robustness, we use each component of InfoEnv_Index as a dependent variable and rerun model (1). Results reported in Table 3 show positive coefficients on DEA Score when the dependent variable is Analyst Following and Trading Volume, and significantly negative coefficients when the dependent variable is Analyst Forecast Error and Bid-Ask Spread, consistent with managerial ability improving information environment. These results corroborate those obtained using InfoEnv_Index.

\section{Robustness Tests}

\subsection{Self-Selection Test}

As highlighted in Francis et al. (2008), it is possible that firms with higher quality information environments employ higher ability managers. If so, then this suggests that selfselection might drive our results. However, Francis et al. (2008) provide evidence that firms with lower quality information environments employ higher ability managers to improve their information environment. This evidence notwithstanding, we follow Francis et al. (2008) and 
perform a simultaneous equations analysis to rule out the possibility that self-selection drives our results. We use model (1) as a determinant model of firms' information environment and use the following model (2) as a determinant model of managerial ability, following Himmelberg and Hubbard (2000) and Francis et al. (2008):

Ability $=\alpha+\beta_{1}$ InfoEnv_Index $+\beta_{2}$ Size $+\beta_{3}$ Market to Book $+\beta_{4}$ Current Returns $+\beta_{5}$ Past Returns $+\beta_{6}$ Current ROA + $\beta_{7}$ Tenure + 88 Age Dummy $+\beta 9$ Age Dummy * Age $+\beta_{10} R \& D$ Dummy $+\beta_{11} R \& D$ Dummy * R\&D + $\beta_{12}$ Advertising Dummy $+\beta 13$ Advertising Dummy *Advertising $+\varepsilon$,

where Ability, InfoEnv_Index, and Size are defined in model (1). We include three firm performance measures: Current Returns, Current Returns, and Current ROA. Current Returns is current year's market returns. Past Returns is last year's market returns. Current ROA is return on assets, measured as income before extraordinary items divided by total assets of current year. We include three intangible intensity using the market-to-book ratio, research and development (R\&D) expenditures, and advertising expenditures. Market to Book is the market to book ratio measured by market value of common equity divided by book value of equity. $R \& D$ is measured as research and development expenses divided by sales. Advertising is measured as advertising expenses divided by sales. Because many firms do not report $R \& D$ and advertising expenditures, we include a reporting dummy variable to address this issue. $R \& D$ Dummy equals 1 if a value for $R \& D$ is reported on Compustat, and 0 otherwise. Advertising Dummy equals 1 if a value for advertising is reported on Compustat, and 0 otherwise. Finally, we include CEO characteristics such as CEO tenure and CEO age. Tenure is the number of years that a CEO has the CEO position. Age is a CEO's age. Age Dummy is set to 1 if an age value is reported on ExecuComp, and 0 otherwise.

We report in Table 4 that InfoEnv_Index is positively related to managerial ability, even 
after controlling for simultaneous equations. This result is consistent with results in Table 3 . Thus, self-selection bias does not appear to drive our main results. The first stage determinant models of managerial ability and information environment have an $\mathrm{R}^{2}$ of 0.712 and 0.846 , respectively, indicating substantial explanatory power of our instruments. Weak instrument tests further show that the minimum eigenvalue statistics of 167.10 and 57.90 exceed thresholds established in Stock and Yogo (2005), thereby rejecting the null hypothesis that our instruments are weak. Finally, the Hausman (1978) test statistics reported in Table 4 also support the need to control endogeneity through simultaneous equations.

\section{[Insert Table 4 here]}

\subsection{Alternative Measures of Managerial Ability}

To provide additional support for our results, we next assess the robustness of our main results based on two alternative measures of managerial ability. We follow Rajgopal et al. (2006) and use industry-adjusted ROA (IndAdjROA) for the prior three years for a particular CEO for each firm-year as our first alternative measure of managerial ability. We construct IndAdjROA using income before extraordinary items scaled by average total assets for each firm and subtract from it the median ROA for firms with the same two-digit SIC code for each firm-year.

For our second alternative measure of managerial ability, we follow Milbourn (2003), Rajgopal et al. (2006), and Francis et al. (2008), and use CEO press citations. The intuition behind this measure is that a CEO who is perceived to be an expert is more likely to be interviewed and cited than a CEO who is not considered to be an expert. Thus, the press citation measure of CEO ability likely reflects the market's assessment of a CEO's perceived ability (Milbourn 2003). 
Similar to research employing press citations as a proxy for managerial ability, we hand-collect CEOs' press citations by searching news articles from all publications in the Factiva database. We code the number of news articles that mention the CEO's name and company. For each sample year, we sum the number of citations over the prior five years to measure ability because it is reasonable to assume that a $\mathrm{CEO}$ develops his/her ability over a number of years.

Although the press citation measure has been employed in published research (e.g., Francis et al. 2008), we nevertheless perform a validation test of this measure similar to that performed in prior research. A key assumption linking press citations and CEO ability is that, compared to CEOs of low repute, the press is more likely to cite CEOs of high repute. It could be the case, however, that the tone of the articles might be negative, thus negating the underlying reason for using the number of news articles. To mitigate this concern, we randomly select $100 \mathrm{CEOs}$ in our sample and randomly choose 10 news articles for each of these CEOs. We then examine these articles, noting their tone. We find that $95 \%$ of the articles portray CEOs in neutral (75\%) or positive tones (20\%) (untabulated), thus validating press citations as a reasonable proxy of ability without considering the specific content of the articles. The results of our validation tests are consistent with those reported in prior research (Milbourn 2003; Rajgopal et al. 2006; Francis et al. 2008). In untabulated results, we find that our main inferences are unaffected using industry-adjusted ROA and press citations as alternative measures of managerial ability.

\section{Additional Tests}

\subsection{Equity Incentives}

As we argued earlier, if equity incentives influence managers' disclosure choices, then we expect to observe a more pronounced relation between managerial ability and firms' information 
environment when managers' equity incentives are greater. We argue that equity-based compensation provides high ability managers with incentives to enhance financial reporting (Milbourn 2003). Improving the information environment through disclosure quality is related to lower cost of capital, which affects firm value (Lang and Lundholm 1996; Botosan 1997; Leuz and Verrecchia 2000; Lambert, Leuz, and Verrecchia 2002; Easley and O'Hara 2004) and, consequently, managers' wealth. However, because high ability managers might prefer rent extraction under an agency problem of partial ownership (Jensen and Meckling 1976; Bebchuk et al. 2002), rent extraction incentives might dominate equity incentives.

We use two measures of equity incentives. For our first measure of equity incentives, we use CEO stock ownership, measured as percentage of shares outstanding held by the CEO. Prior research suggests that $\mathrm{CEO}$ stock ownership provides equity incentives to reduce agency costs Jensen and Meckling 1976; Ang et al. 2000). For our second measure of equity incentives, we use CEO firm-related wealth, measured as the sum of the value of employee stock options exercisable and unexercisable options) and the value of stock shares owned, scaled by firm market value. Employee stock options are typically excluded when measuring ownership, but we include them because CEOs' compensation structure typically includes significant portions of option-based compensation, thus providing CEOs with additional equity incentives. ${ }^{10}$

Table 5 provides regression results for tests investigating how equity incentives affect the relation between managerial ability and information environment. We interact DEA Score and equity incentives (Ownership and Wealth) to examine whether equity incentives increase the

\footnotetext{
${ }^{10}$ We compute the value of stock options based on the Black-Scholes formula, following Core and Guay (2002), Coles et al. (2006), and Daniel et al. (2016). We use the approximation method to determine vested and unvested option shares for the pre-2006 data and we use the disclosed number of option shares (vested and unvested) for data in the subsequent period, following Coles et al (2013).
} 
positive effect of managerial ability on information environment. In Table 5, we report that the coefficients on DEA Score*Ownership and DEA Score*Wealth are significantly positive $(\mathrm{p}<0.01$ for both). Overall, the results in Table 5 corroborate our main results and suggest that managers with higher equity incentives improve firms' information environment even more compared to managers with lower equity incentives. These additional results support our argument that equity incentives incentivize high ability managers to enhance their firms' information environment through improved financial reporting.

\section{[Insert Table 5 here]}

\subsection{Rent Extraction Incentives}

Results thus far indicate that firms' information environment is increasing in managerial ability and that equity incentives drive this result. However, even though equity incentives appear to dominate rent extraction incentives, on average, these results do not exclude the possibility that both equity and rent extraction incentives impact information environment quality. Strong corporate governance mechanisms can restrain rent extraction incentives (Shleifer and Vishny 1997; Core, Holthausen, and Larcker 1999) of hiding excessive compensation through opaque disclosures (Bebchuk et al. 2002; Schultz and McGinty 2009). We therefore examine whether rent extraction incentives lead higher ability managers to reduce the quality of their firms' information environment quality when corporate governance is weak. If high ability managers do not do so, even under weak corporate governance, then this would corroborate our prior findings and add further support to the equity incentive story.

We employ two widely used measures of governance to study their influence on the relation between managerial ability and the information environment. For our first measure of governance, we use dedicated institutional ownership, which Bushee (1998) defines as long-term 
buy-and-hold investors that are expected to provide more stringent oversight than short-term investors. We measure dedicated institutional ownership as the percentage of shares held by dedicated institutional investors. ${ }^{11}$ For our second governance measure, we use board of director independence, measured as the proportion of board members who have no affiliation with the firm other than as directors. Independent directors are expected to provide better oversight than nonindependent directors (Fama 1980).

Table 6 provides regression results for tests of the relation between managerial ability and our two measures of a firm's governance environment. We interact DEA Score and corporate governance, measured as dedicated institutional ownership and the independence of directors, to examine whether governance affects the relation between managerial ability and firms' information environment. In Table 6, we report that the coefficients on DEA Score*Dedicated Institutional Ownership and DEA Score*Independent Director\% are significantly negative ( $<<0.05$ for both). Overall, the results in Table 6 suggest that given the opportunity to extract rent, high ability managers are less likely to do so compared to low ability managers. These results corroborate our prior findings and add further support to an equity incentive story that explains why firms with high ability managers have better information environments. The results also suggest that high ability managers play a relatively more important role in improving the information environment in firms with weak governance than in firms with strong governance. Results from this sub-section thus highlight that managerial ability serves as an effective alternative monitoring mechanism when firms' governance mechanisms are weak.

\footnotetext{
${ }^{11}$ See Bushee (1998) for details on the categorization of institutional owners.
} 
[Insert Table 6 here]

\section{Summary and Conclusion}

This study examines the relation between managerial ability and the quality of firms' information environment. There are competing predictions for the existence and direction of the relation between managerial ability and information environment, as well as empirical issues that leave our understanding of the relation between managerial ability and information environment incomplete. Using a large sample of firms over the period 1993-2010 and multiple measures of firms' information environment, we find a positive and economically significant relation between managerial ability and firms' information environment. This evidence is consistent with the notion that overall disclosure in firms with high ability managers is such that it effectively enhances firms' information environment. As in prior studies of managerial ability and financial reporting (e.g., Francis et al. 2008), self-selection bias potentially impacts our results. However, we rule out this possibility via simultaneous equations tests. Our results are also robust to using alternative measures of managerial ability.

We also investigate whether equity-based incentives explain our main results and show that higher levels of managerial stock ownership and firm-related wealth do indeed provide high ability managers with incentives to improve their firms' information environment. Further corroborating the equity incentive story, we also show that higher ability managers enhance firms' information environment more than lower ability managers when firms have a relatively weak governance environment (i.e., when managers are entrenched), as reflected in low dedicated institutional ownership and low board independence. These results imply that high ability managers prefer a better information environment even if there is weak governance within the firm. 
Because managerial ability is difficult to observe directly, results from our study are based on proxies that may embody errors. Notwithstanding this caveat, our study helps to unify prior conflicting research on the question of the impact of managerial ability on information environment. Our study also contributes to the emerging literature on the role of managerial ability as an economic factor affecting firm outcomes. Results from our study should be useful to boards of directors in their hiring and retention decisions, as well as to investors for portfolio decisions. 


\section{References}

Anderson, R., Duru, A., Reeb, D. 2009. Founders, heirs, and corporate opacity in the United States. Journal of Financial Economics 92: 205-222.

Ang, J.S., Cole, R.A., Lin, J.W. 2000. Agency costs and ownership structure. Journal of Finance 55: 81-106.

Baik, B., Choi, S., Farber, D. 2017. Managerial Ability and Income Smoothing. Working paper, Seoul National University.

Baik, B., Farber, D., Lee, S. 2011. CEO ability and management earnings forecasts. Contemporary Accounting Research 28: 1645-1668.

Baik, B., Kang, J., Morton, R. 2010. Why are analysts less likely to follow firms with high managerial ownership? Journal of Accounting, Auditing \& Finance 25(2): 171-200.

Bamber, L., Jiang, J., Wang, I. 2010. What's my style? The influence of top managers on voluntary corporate financial disclosure. The Accounting Review 85: 1131-1162.

Barth, M.E., Kasznik, R., McNichols, M.F. 2001. Analyst coverage and intangible assets. Journal of Accounting Research 39: 1-34.

Beasley, M. 1996. An empirical analysis of the relation between the board of director composition and financial statement fraud. The Accounting Review 71: 443-465.

Bebchuk, L., J. Fried. 2004. Stealth compensation via retirement benefits. Berkeley Business Law Journal 1 (2): 291-326.

Bebchuk, L., Fried, J., Walker, D. 2002. Managerial power and rent extraction in the design of executive compensation. University of Chicago Law Review 69: 751-846.

Bertrand, M., Schoar, A. 2003. Managing with style: The effect of managers on firm policies. Quarterly Journal of Economics 118: 1169-1208.

Beyer, A., Cohen, D.A., Lys, T.Z., Walther, B.R. 2010. The financial reporting environment: Review of the recent literature. Journal of Accounting and Economics 50 (2-3): 296343.

Bhushan, R. 1989. Firm characteristics and analyst following. Journal of Financial Economics 11: 255-274.

Botosan, C. 1997. Disclosure level and the cost of equity capital. The Accounting Review 72: 323-349.

Botosan, C., Plumlee, M., Xie, Y. 2004. The role of information precision in determining cost of equity capital. Review of Accounting Studies 9: 121-137. 
Brown, L.D., Call, A.C., Clement, M.B., Sharp, N.Y. 2015. Inside the "Black Box" of sellside financial analysts. Journal of Accounting Research 53: 1-47.

Bushee, B. 1998. The influence of institutional investors on myopic R\&D investment behavior. The Accounting Review 73: 305-333.

Bushee, B., Matsumoto, D.A., Miller, G.S. 2003. Open versus closed conference calls: the determinants and effects of broadening access to disclosure. Journal of Accounting and Economics 34(1-3): 149-180.

Bushee, B., Noe, C. 2000. Corporate disclosure practices, institutional investors, and stock return volatility. Journal of Accounting Research 38: 171-202.

Bushman, R., Chen, Q., Engel, E., Smith, A. 2004. Financial accounting information, organizational complexity and corporate governance systems. Journal of Accounting and Economics 37: 167-201.

Chen, X., Cheng, Q., Wang, X. 2011. Does increased board independence reduce earnings management? Evidence from recent regulatory reforms. Working paper, Singapore Management University.

Coff, R.W. 1997. Human assets and management dilemmas: coping with hazards on the road to resource-based theory. Academy of Management Review 22 (2): 374-402.

Coles, J., Daniel, N., Naveen, L. 2006. Managerial incentives and risk-taking. Journal of Financial Economics 79: 431-468.

Coles, J., Daniel, N., Naveen, L. 2013. Calculation of compensation incentives and firmrelated wealth using ExecuComp: Data, program, and explanation. Working Paper.

Core, J.E., Guay, W. 2002. Estimate the value of employee stock option portfolios and their sensitivities to price and volatility. Journal of Accounting Research 40: 613-630.

Daniel, N., Li, Y., Naveen, L. 2016. No asymmetry in pay for luck: A size effect? Working Paper.

Dechow, P., Ge, W., Schrand, C. 2010. Understanding earnings quality: A review of the proxies, their determinants and their consequences. Journal of Accounting and Economics 50 (2 3): 344-401.

Dechow, P., Sloan, R., Sweeney, A. 1996. Causes and consequences of earnings manipulation: an analysis of firms subject to enforcement actions by the SEC. Contemporary Accounting Research 13: 1-36.

Demerjian, P., Lev, B., Lewis, M., McVay, S. 2013. Managerial ability and earnings quality. The Accounting Review 88: 463-498. 
Demerjian, P., Lev, B., McVay, S. 2012. Quantifying managerial ability: A new measure and validity tests. Management Science 58: 1229-1248.

Diamond, D., Verrecchia, R. 1991. Disclosure, liquidity, and the cost of capital. Journal of Finance 46: 1325-1360.

Drake, M., Myers L., Scholz, S., Sharp, N. 2015. Short selling around restatement announcements: When do bears pounce? Journal of Accounting Auditing \& Finance 30 (2): 218-245.

Easley, D., O'Hara, M. 2004. Information and the cost of capital. Journal of Finance 59: 1029 1583.

Fama, E.F. 1980. Agency problems and the theory of the firm. Journal of Political Economy 88: $288-307$.

Francis, J., Hanna, J.D., Philbrick, D.R. 1997. Management communications with securities analysts. Journal of Accounting and Economics 24: 363-394.

Francis, J., Huang, A., Rajgopal, S., Zang, A. 2008. CEO ability and earnings quality. Contemporary Accounting Research 25: 109-147.

Frankel, R., Johnson, M., Skinner, D. 1999. An empirical examination of conference calls as a voluntary disclosure medium. Journal of Accounting Research 37(1): 133-150.

Frankel, R., Kothari, S. P., Weber, J. 2006. Determinants of the informativeness of analyst research. Journal of Accounting and Economics 41: 29-54.

Hausman, J. A. 1978. Specification tests in econometrics. Econometrica 46: 1251-1271.

Healy, P.M., Hutton, A.P., Palepu, K.G. 1999. Stock performance and intermediation changes surrounding sustained increases in disclosure. Contemporary Accounting Research 16: 485-520.

Hermalin, B., Weisbach, M. 1998. Endogenously chosen boards of directors and their monitoring of the CEO. The American Economic Review 88 (1): 96-118.

Himmelberg, C., Hubbard, G. 2000. Incentive pay and the market for CEOs: An analysis of pay-for-performance sensitivity. Working paper, Columbia University.

Hilary, G. 2006. Organized labor and information asymmetry in the financial markets. Review of Accounting Studies 11: 525-548.

Jensen, M.C., Meckling, W.H. 1976. Theory of the firm: Managerial behavior, agency costs and ownership structure. Journal of Financial Economics 3: 305-360.

Kalyta, P., Magnan, M. 2008. Executive pensions, disclosure quality, and rent extraction. Journal of Accounting and Public Policy 27: 133-166. 
Karamanou, I., Vafeas, I. 2005. The association between corporate board, audit committees, and management earnings forecasts: An empirical analysis. Journal of Accounting Research 43: 453-486.

Klein, A. 2002. Audit committee, board of director characteristics, and earnings management. Journal of Accounting and Economics 33: 375- 400.

Lambert, R., Leuz, C., Verrecchia, R. 2002. Accounting information, disclosure, and the cost of capital, Journal of Accounting Research 45: 385 - 420.

Lang, M., Lundholm, R. 1993. Cross-sectional determinants of analyst ratings of corporate disclosures. Journal of Accounting Research 31: 246-271.

Lang, M., Lundholm, R. 1996. Corporate disclosure policy and analyst behavior. The Accounting Review 71: 467-492.

Leuz, C., Verrecchia, R. 2000. The economic consequences of increased disclosure. Journal of Accounting Research 38: 91-124.

Lim, T. 2001. Rationality and analysts' forecast bias. Journal of Finance 56: 369-385.

Lo, A., Mamaysky, H., Wang, J. 2004. Asset prices and trading volume under fixed transaction costs. Journal of Political Economy 112: 1054-1090.

Mahoney, J.T. 1995. The management of resources and the resources of management. Journal of Business Research 33 (2): 91-101.

Malmendier, U., Tate, G., 2009. Superstar CEOs. Quarterly Journal of Economics. 124: 1593-1638.

Milbourn, T. 2003. CEO ability and stock-based compensation. Journal of Financial Economics 68: 233-262.

O'Brien, P.C., Bhushan, R. 1990. Analyst following and institutional ownership. Journal of Accounting Research 28: 55-76.

Rajgopal, S., Shevlin, T., Zamora, V. 2006. CEOs' outside employment opportunities and the lack of relative performance evaluation in compensation contracts. Journal of Finance 61: 1813-1844.

Schultz, E., McGinty, T. 2009. Filings don't tell full pension story. The Wall Street Journal (November 4): M7.

Shleifer, A., Vishny, R. 1997. A survey of corporate governance. Journal of Finance 52: 737783. 
Stock, J.H., Yogo, M. 2005. Testing for weak instruments in linear IC regression. In Identification and inference for econometric models: Essays in honor of Thomas Rothenberg, ed. Andrews, D.W.K., Stock, J.H., 80-108. New York: Cambridge University Press.

Tasker, S.C. 1998. Bridging the information gap: Quarterly conference calls as a medium for voluntary disclosure. Review of Accounting Studies 3: 137-167.

Trueman, B. 1986. Why do managers voluntarily release earnings forecasts? Journal of Accounting and Economics 8: 53-71. 
Table 1

Descriptive Statistics

\begin{tabular}{lrrrrrr}
\hline Variable & $\mathrm{N}$ & \multicolumn{1}{c}{ Mean } & Std. Dev. & Q1 & Median & \multicolumn{1}{c}{$\mathrm{Q} 3$} \\
\hline InfoEnv_Index & 15,207 & 0.567 & 0.205 & 0.425 & 0.575 & 0.725 \\
Analyst Following & 15,207 & 11.845 & 7.269 & 6.000 & 10.000 & 16.000 \\
Analyst Forecast Error & 15,207 & 0.005 & 0.034 & 0.000 & 0.001 & 0.003 \\
Trading Volume & 15,207 & 47.664 & 103.075 & 3.654 & 11.427 & 38.557 \\
Bid-Ask Spread & 15,207 & 0.008 & 0.009 & 0.001 & 0.003 & 0.011 \\
DEA Score & 15,207 & 0.018 & 0.133 & -0.069 & 0.007 & 0.094 \\
Size & 15,207 & $4,804.6$ & $10,274.8$ & 478.0 & $1,257.5$ & $3,861.2$ \\
Risk & 15,207 & 0.126 & 0.062 & 0.082 & 0.111 & 0.153 \\
Performance & 15,207 & 0.050 & 0.096 & 0.024 & 0.058 & 0.096 \\
Firm Age & 15,207 & 22.507 & 19.021 & 9.000 & 16.000 & 32.000 \\
Growth & 15,207 & 0.041 & 0.067 & 0.000 & 0.007 & 0.057 \\
Leverage & 15,207 & 0.178 & 0.163 & 0.018 & 0.156 & 0.281 \\
Disclose & 15,207 & 0.397 & 0.489 & 0.000 & 0.000 & 1.000 \\
Accrual Quality & 15,207 & -0.036 & 0.049 & -0.044 & -0.023 & -0.010 \\
Smoothing & 15,207 & -1.148 & 1.560 & -1.318 & -0.829 & -0.505 \\
\hline
\end{tabular}

This Table reports the descriptive statistics for the variables used in the regression analyses. InfoEnv_Index is a composite index of information environment, measured by ranking the four individual proxies for information environment (trading volume, bid-ask spread, analyst following, and analyst forecast errors) into deciles in which firms with the highest information environment have a value of 10 . The four rankings are then summed and divided by 40 (total possible points), yielding a measure that ranges between 1 (highest information environment quality) and 0.1 (lowest information environment quality). Analyst Following is the number of analysts providing earnings per share estimates nine months prior to fiscal year-end. Analyst Forecast Error is the absolute value of the difference between the mean analysts' earnings forecast (nine months prior to fiscal year-end) and actual firm earnings scaled by the firm's stock price at the beginning of the fiscal year. Trading Volume is the average daily trading volume (in \$million) over the fiscal year. Bid-Ask Spread is measured as the ask price minus the bid price divided by average of the bid and ask prices. DEA Score is our proxy for managerial ability and is based on the measure developed in Demerjian et al. (2012). Size is firm size, measured using total assets (in \$million). Risk is the standard deviation of monthly stock returns for the previous 36 months. Performance is return on assets, measured as income before extraordinary items divided by average total assets from the prior year. Firm Age is the number of years since the firm was first listed on CRSP. Growth is firm growth opportunities, measured as research and development expenses divided by total assets (R\&D Expenses / total assets). Leverage is firm leverage, measured as total long-term debt divided by total assets. Disclose is a dummy variable of management forecast likelihood set equal to 1 if there is an annual management earnings forecast in year t, 0 otherwise, following Baik et al. (2011). Accrual Quality is measured using a modified Dechow and Dichev (2002) accrual model, following Demerjian et al. (2013). For easier interpretation, Accrual Quality is multiplied by negative one to indicate that a high number indicates high accrual quality. Smoothing is income smoothing measured by the standard deviation of earnings divided by the standard deviation of cash flows from operations, where earnings and cash flows are scaled by lagged total assets following Baik et al (2017). For easier interpretation, Smoothing is multiplied by negative one to indicate that a high number indicates high smoothing. 
Table 2

Pearson Correlations between Variables

\begin{tabular}{|c|c|c|c|c|c|c|c|c|c|c|c|}
\hline & InfoEnv_Index & $\begin{array}{l}\text { DEA } \\
\text { Score } \\
\end{array}$ & Size & Risk & Performance & Frim Age & Growth & Leverage & Disclose & $\begin{array}{l}\text { Accrual } \\
\text { Quality }\end{array}$ & Smoothing \\
\hline \multirow[t]{2}{*}{ InfoEnv_Index } & 1.000 & 0.125 & 0.615 & -0.256 & 0.250 & 0.168 & 0.077 & -0.049 & 0.251 & 0.076 & 0.022 \\
\hline & & $<.0001$ & $<.0001$ & $<.0001$ & $<.0001$ & $<.0001$ & $<.0001$ & $<.0001$ & $<.0001$ & $<.0001$ & 0.006 \\
\hline \multirow[t]{2}{*}{ DEA Score } & & 1.000 & -0.011 & -0.101 & 0.328 & -0.021 & -0.082 & -0.097 & 0.030 & 0.012 & 0.129 \\
\hline & & & 0.180 & $<.0001$ & $<.0001$ & 0.009 & $<.0001$ & $<.0001$ & 0.000 & 0.128 & $<.0001$ \\
\hline \multirow[t]{2}{*}{ Size } & & & 1.000 & -0.407 & -0.051 & 0.445 & -0.145 & 0.348 & 0.162 & 0.145 & 0.031 \\
\hline & & & & $<.0001$ & $<.0001$ & $<.0001$ & $<.0001$ & $<.0001$ & $<.0001$ & $<.0001$ & 0.000 \\
\hline \multirow[t]{2}{*}{ Risk } & & & & 1.000 & -0.254 & -0.386 & 0.188 & -0.117 & -0.136 & -0.237 & -0.223 \\
\hline & & & & & $<.0001$ & $<.0001$ & $<.0001$ & $<.0001$ & $<.0001$ & $<.0001$ & $<.0001$ \\
\hline \multirow[t]{2}{*}{ Performance } & & & & & 1.000 & 0.015 & 0.002 & -0.319 & 0.103 & 0.081 & 0.199 \\
\hline & & & & & & 0.068 & 0.788 & $<.0001$ & $<.0001$ & $<.0001$ & $<.0001$ \\
\hline \multirow[t]{2}{*}{ Frim Age } & & & & & & 1.000 & -0.052 & 0.152 & 0.055 & 0.135 & 0.050 \\
\hline & & & & & & & $<.0001$ & $<.0001$ & $<.0001$ & $<.0001$ & $<.0001$ \\
\hline \multirow[t]{2}{*}{ Growth } & & & & & & & 1.000 & -0.302 & -0.040 & -0.143 & -0.229 \\
\hline & & & & & & & & $<.0001$ & $<.0001$ & $<.0001$ & $<.0001$ \\
\hline \multirow[t]{2}{*}{ Leverage } & & & & & & & & 1.000 & 0.042 & 0.093 & -0.021 \\
\hline & & & & & & & & & $<.0001$ & $<.0001$ & 0.010 \\
\hline \multirow[t]{2}{*}{ Disclose } & & & & & & & & & 1.000 & 0.092 & 0.086 \\
\hline & & & & & & & & & & $<.0001$ & $<.0001$ \\
\hline \multirow[t]{2}{*}{ Accrual Quality } & & & & & & & & & & 1.000 & 0.178 \\
\hline & & & & & & & & & & & $<.0001$ \\
\hline Smoothing & & & & & & & & & & & 1.000 \\
\hline
\end{tabular}

This Table reports the Pearson correlations between the variables used in the regression analyses. InfoEnv_Index is a composite index of information environment, measured by ranking the four individual proxies for information environment (trading volume, bid-ask spread, analyst following, and analyst forecast errors) into deciles in which firms with the highest information environment have a value of 10 . The four rankings are then summed and divided by 40 (total possible points), yielding a measure that ranges between 1 (highest information environment quality) and 0.1 (lowest information environment quality).

$\boldsymbol{D E} \boldsymbol{A}$ Score is our proxy for managerial ability and is based on the measure developed in Demerjian et al. (2012). Size is firm size, measured using total assets (in \$million). Risk is the standard deviation of monthly stock returns for the previous 36 months. Performance is return on assets, measured as income before extraordinary items divided by average total assets from the prior year. Firm Age is the number of years since the firm was first listed on CRSP. Growth is firm 
growth opportunities, measured as research and development expenses divided by total assets (R\&D Expenses / total assets). Leverage is firm leverage, measured as total long-term debt divided by total assets. Disclose is a dummy variable of management forecast likelihood set equal to 1 if there is an annual management earnings forecast in year t, 0 otherwise, following Baik et al. (2011). Accrual Quality is measured using a modified Dechow and Dichev (2002) accrual model, following Demerjian et al. (2013). For easier interpretation, Accrual Quality is multiplied by negative one to indicate that a high number indicates high accrual quality. Smoothing is income smoothing measured by the standard deviation of earnings divided by the standard deviation of cash flows from operations, where earnings and cash flows are scaled by lagged total assets following Baik et al (2017). For easier interpretation, Smoothing is multiplied by negative one to indicate that a high number indicates high smoothing. 
Table 3

Regressions of Information Environment Measures on Managerial Ability

\begin{tabular}{|c|c|c|c|c|c|c|}
\hline $\begin{array}{l}\text { Dependent } \\
\text { Variables }\end{array}$ & $\begin{array}{l}\text { Predicted } \\
\text { Sign }\end{array}$ & $\begin{array}{l}\text { InfoEnv } \\
\text { Index }\end{array}$ & $\begin{array}{c}\text { Analyst } \\
\text { Following }\end{array}$ & $\begin{array}{c}\text { Analyst } \\
\text { Forecast } \\
\text { Error }\end{array}$ & $\begin{array}{l}\text { Trading } \\
\text { Volume }\end{array}$ & $\begin{array}{l}\text { Bid-Ask } \\
\text { Spread }\end{array}$ \\
\hline DEA Score & & $\begin{array}{c}\mathbf{0 . 0 5 6 * * *} \\
{[12.19]}\end{array}$ & $\begin{array}{c}0.016 * * \\
{[2.37]}\end{array}$ & $\begin{array}{c}-0.065 * * * \\
{[-5.55]}\end{array}$ & $\begin{array}{c}0.091 * * * \\
{[17.67]}\end{array}$ & $\begin{array}{c}-0.052 * * * \\
{[-10.39]}\end{array}$ \\
\hline Size & + & $\begin{array}{c}0.479 * * * \\
{[45.44]}\end{array}$ & $\begin{array}{c}0.671 * * * \\
{[42.86]}\end{array}$ & $\begin{array}{c}-0.269^{* * * *} \\
{[-10.12]}\end{array}$ & $\begin{array}{c}0.668^{* * * *} \\
{[56.48]}\end{array}$ & $\begin{array}{c}-0.307 * * * \\
{[-26.53]}\end{array}$ \\
\hline Risk & - & $\begin{array}{l}-0.006 \\
{[-1.11]}\end{array}$ & $\begin{array}{l}-0.001 \\
{[-0.11]}\end{array}$ & $\begin{array}{c}0.108 * * * \\
{[7.46]}\end{array}$ & $\begin{array}{c}0.119^{* * *} \\
{[18.48]}\end{array}$ & $\begin{array}{c}0.036^{* * *} \\
{[5.66]}\end{array}$ \\
\hline Performance & + & $\begin{array}{c}0.115^{* * *} \\
{[27.29]}\end{array}$ & $\begin{array}{c}0.095^{* * *} \\
{[15.06]}\end{array}$ & $\begin{array}{c}-0.138^{* * * *} \\
{[-12.98]}\end{array}$ & $\begin{array}{c}0.146^{* * *} \\
{[30.78]}\end{array}$ & $\begin{array}{c}-0.082 * * * \\
{[-17.75]}\end{array}$ \\
\hline Frim Age & $?$ & $\begin{array}{c}-0.034^{* *} \\
{[-2.46]}\end{array}$ & $\begin{array}{c}0.075^{* * *} \\
{[3.71]}\end{array}$ & $\begin{array}{l}0.023 \\
{[0.68]}\end{array}$ & $\begin{array}{c}-0.110^{* * *} \\
{[-7.19]}\end{array}$ & $\begin{array}{c}0.076^{* * *} \\
{[5.08]}\end{array}$ \\
\hline Growth & $?$ & $\begin{array}{c}-0.031^{* *} \\
{[-1.97]}\end{array}$ & $\begin{array}{l}-0.006 \\
{[-0.25]}\end{array}$ & $\begin{array}{c}0.133 * * * \\
{[3.36]}\end{array}$ & $\begin{array}{l}0.019 \\
{[1.10]}\end{array}$ & $\begin{array}{l}0.004 \\
{[0.23]}\end{array}$ \\
\hline Leverage & - & $\begin{array}{c}-0.038 * * * \\
{[-7.38]}\end{array}$ & $\begin{array}{c}-0.044 * * * \\
{[-5.79]}\end{array}$ & $\begin{array}{c}0.050 * * * \\
{[3.86]}\end{array}$ & $\begin{array}{c}-0.036^{* * * *} \\
{[-6.32]}\end{array}$ & $\begin{array}{c}0.021 * * * \\
{[3.72]}\end{array}$ \\
\hline Disclose & + & $\begin{array}{c}0.018^{* * * *} \\
{[7.69]}\end{array}$ & $\begin{array}{c}0.013 * * * \\
{[3.62]}\end{array}$ & $\begin{array}{c}-0.040 * * * \\
{[-6.80]}\end{array}$ & $\begin{array}{c}0.017^{* * * *} \\
{[6.43]}\end{array}$ & $\begin{array}{l}-0.002 \\
{[-0.92]}\end{array}$ \\
\hline Accrual Quality & + & $\begin{array}{c}0.013 * * * \\
{[3.83]}\end{array}$ & $\begin{array}{c}0.018^{* * *} \\
{[3.76]}\end{array}$ & $\begin{array}{c}-0.028 * * * \\
{[-3.42]}\end{array}$ & $\begin{array}{l}-0.002 \\
{[-0.43]}\end{array}$ & $\begin{array}{l}-0.005 \\
{[-1.47]}\end{array}$ \\
\hline Smoothing & + & $\begin{array}{c}0.015^{* * *} \\
{[4.10]}\end{array}$ & $\begin{array}{l}0.011^{*} \\
{[1.89]}\end{array}$ & $\begin{array}{c}-0.034 * * * \\
{[-3.61]}\end{array}$ & $\begin{array}{l}0.003 \\
{[0.69]}\end{array}$ & $\begin{array}{c}-0.014 * * * \\
{[-3.37]}\end{array}$ \\
\hline Constant & & $\begin{array}{c}0.537 * * * \\
{[89.15]} \\
\end{array}$ & $\begin{array}{c}0.784 * * * \\
{[87.60]} \\
\end{array}$ & $\begin{array}{c}0.526 * * * \\
{[34.61]}\end{array}$ & $\begin{array}{c}0.467 * * * \\
{[68.91]} \\
\end{array}$ & $\begin{array}{l}0.776 * * * \\
{[117.46]}\end{array}$ \\
\hline Firm Fixed Effects & & Yes & Yes & Yes & $\begin{array}{l}\text { Yes } \\
\text { Yes }\end{array}$ & $\begin{array}{l}\text { Yes } \\
\text { Yes }\end{array}$ \\
\hline $\begin{array}{l}\text { Year Fixed Effects } \\
\text { Observations }\end{array}$ & & $\begin{array}{c}\text { Yes } \\
15,027\end{array}$ & $\begin{array}{c}\text { Yes } \\
15,027\end{array}$ & $\begin{array}{c}\text { Yes } \\
15,027\end{array}$ & $\begin{array}{c}\text { Yes } \\
15,027\end{array}$ & $\begin{array}{c}\text { Yes } \\
15,027\end{array}$ \\
\hline R-squared & & 0.819 & 0.802 & 0.406 & 0.881 & 0.884 \\
\hline
\end{tabular}

This Table reports the regression results for an association between InfoEnv_Index and DEA Scores. InfoEnv_Index is a composite index of information environment, measured by ranking the four individual proxies for information environment (trading volume, bid-ask spread, analyst following, and analyst forecast errors) into deciles in which firms with the highest information environment have a value of 10 . The four rankings are then summed and divided by 40 (total possible points), yielding a measure that ranges between 1 (highest information environment quality) and 0.1 (lowest information environment quality). Analyst Following is the number of analysts providing earnings per share estimates nine months prior to fiscal year-end. Analyst Forecast Error is the absolute value of the difference between the mean analysts' earnings forecast (nine months prior to fiscal year-end) and actual firm earnings scaled by the firm's stock price at the beginning of the fiscal year. Trading Volume is the average daily trading volume (in \$million) over the fiscal year. Bid-Ask Spread is measured as the ask price minus the bid price divided by average of the bid and ask prices. DEA Score is our proxy for managerial ability and is based on the measure developed in Demerjian et al. (2012). Size is firm size, measured using total assets (in \$million). Risk is the standard deviation of monthly stock returns for the previous 36 months. Performance is return on assets, measured as income before extraordinary items divided by average total assets from the prior year. Firm Age is the number of years since the firm was first listed on CRSP. Growth is firm growth opportunities, measured as research and development expenses divided by total assets (R\&D Expenses / total assets). Leverage is firm leverage, measured as total long-term debt divided by total assets. Disclose is a dummy variable of management forecast likelihood set equal to 1 if there is an annual management earnings forecast in year t, 0 otherwise, following (Baik et al. 2011). Accrual Quality is measured using a modified Dechow and Dichev (2002) accrual model, following Demerjian et al. 
(2013). For easier interpretation, Accrual Quality is multiplied by negative one to indicate that a high number indicates high accrual quality. Smoothing is income smoothing measured by the standard deviation of earnings divided by the standard deviation of cash flows from operations, where earnings and cash flows are scaled by lagged total assets following Baik et al (2017). For easier interpretation, Smoothing is multiplied by negative one to indicate that a high number indicates high smoothing. Continuous variables are ranked by deciles and divided by 10 for comparability with the InfoEnv_Index. $* * *, * * *$ indicates significance at the $0.01,0.05$, and 0.10 levels, respectively (two-tailed). 
Table 4

Simultaneous Equations Analysis

of Information Environment and Managerial Ability

\begin{tabular}{|c|c|c|c|}
\hline Independent Variables & $\begin{array}{l}\text { Predicted } \\
\text { Sign }\end{array}$ & $D V: D E A$ Score & $D V:$ InfoEnv_Index \\
\hline DEA Score & & & $\begin{array}{c}0.363 * * * \\
{[25.64]}\end{array}$ \\
\hline Size &,-+ & $\begin{array}{c}-0.329 * * * \\
{[-6.30]}\end{array}$ & $\begin{array}{c}0.443 * * * \\
{[37.55]}\end{array}$ \\
\hline Risk & - & & $\begin{array}{l}0.005 \\
{[0.81]}\end{array}$ \\
\hline Performance & + & & $\begin{array}{c}0.052 * * * \\
{[9.61]}\end{array}$ \\
\hline Firm Age & $?$ & & $\begin{array}{l}-0.000 \\
{[-0.01]}\end{array}$ \\
\hline Growth & $?$ & & $\begin{array}{c}-0.119 * * * \\
{[-6.79]}\end{array}$ \\
\hline Leverage & - & & $\begin{array}{c}-0.027 * * * \\
{[-4.73]}\end{array}$ \\
\hline Disclose & + & & $\begin{array}{c}0.012 * * * \\
{[4.50]}\end{array}$ \\
\hline Accrual Quality & + & & $\begin{array}{c}0.013 * * * \\
{[3.77]}\end{array}$ \\
\hline Smoothing & + & & $\begin{array}{c}0.005 \\
{[1.10]}\end{array}$ \\
\hline InfoEnv_Index & & $\begin{array}{c}0.957 * * * \\
{[10.37]}\end{array}$ & \\
\hline Market to Book & & $\begin{array}{c}-0.072 * * * \\
{[-3.80]}\end{array}$ & \\
\hline Current Returns & & $\begin{array}{c}0.073 * * * \\
{[6.58]}\end{array}$ & \\
\hline Past Returns & & $\begin{array}{c}0.042 * * * \\
{[6.22]}\end{array}$ & \\
\hline Current ROA & & $\begin{array}{c}0.200 * * * \\
{[16.38]}\end{array}$ & \\
\hline Tenure & & $\begin{array}{c}-0.030 * * * \\
{[-3.57]}\end{array}$ & \\
\hline Age Dummy & & $\begin{array}{c}-0.015^{* *} \\
{[-2.38]}\end{array}$ & \\
\hline Age Dummy * Age & & $\begin{array}{c}0.035 * * * \\
{[3.37]}\end{array}$ & \\
\hline$R \& D$ Dummy & & $\begin{array}{c}-0.030 * * \\
{[-2.48]}\end{array}$ & \\
\hline$R \& D$ Dummy * R\&D & & $\begin{array}{l}-0.000 \\
{[-0.01]}\end{array}$ & \\
\hline Advertising Dummy & & $0.025 * *$ & \\
\hline
\end{tabular}




\begin{tabular}{lcc} 
Advertising Dummy & $-0.117^{* * *}$ & \\
*Advertising & {$[-2.62]$} & \\
Constant & $-0.679^{* * *}$ & $0.540^{* * *}$ \\
& {$[-9.94]$} & {$[18.59]$} \\
\hline Firm Fixed Effects & Yes & Yes \\
\hline Year Fixed Effects & Yes & 14,563 \\
\hline Observations & 14,563 & 0.846 \\
\hline $1^{\text {st }}$ Stage R-squared & 0.712 & 0.637 \\
\hline $2^{\text {nd }}$ Stage R-squared & 0.763 & 57.90 \\
\hline \multirow{2}{*}{ Weak instrument test } & 167.10 & $(5 \%$ bias: 20.25$)$ \\
& $(5 \%$ bias: 20.90$)$ & $(10 \%$ size: 33.84$)$ \\
\hline \multirow{2}{*}{ Hausman test } & $(10 \%$ size: 40.90$)$ & $\mathrm{F}=101.85$ \\
& $\mathrm{~F}=662.86$ & $(\mathrm{p}<0.01)$ \\
\hline
\end{tabular}

This Table reports results from a simultaneous equations analysis for an association between InfoEnv_Index and DEA Score. InfoEnv_Index is a composite index of information environment, measured by ranking the four individual proxies for information environment (trading volume, bid-ask spread, analyst following, and analyst forecast errors) into deciles in which firms with the highest information environment have a value of 10 . The four rankings are then summed and divided by 40 (total possible points), yielding a measure that ranges between 1 (highest information environment quality) and 0.1 (lowest information environment quality). DEA Score is our proxy for managerial ability and is based on the measure developed in Demerjian et al. (2012). Size is firm size, measured using total assets (in \$million). Risk is the standard deviation of monthly stock returns for the previous 36 months. Performance is return on assets, measured as income before extraordinary items divided by average total assets from the prior year. Firm $\boldsymbol{A g e}$ is the number of years since the firm was first listed on CRSP. Growth is firm growth opportunities, measured as research and development expenses divided by total assets (R\&D Expenses / total assets). Leverage is firm leverage, measured as total long-term debt divided by total assets. Disclose is a dummy variable of management forecast likelihood set equal to 1 if there is an annual management earnings forecast in year t, 0 otherwise, following Baik et al. (2011). Accrual Quality is measured using a modified Dechow and Dichev (2002) accrual model, following Demerjian et al. (2013). For easier interpretation, Accrual Quality is multiplied by negative one to indicate that a high number indicates high accrual quality. Smoothing is income smoothing measured by the standard deviation of earnings divided by the standard deviation of cash flows from operations, where earnings and cash flows are scaled by lagged total assets, following Baik et al (2017). For easier interpretation, Smoothing is multiplied by negative one to indicate that a high number indicates high smoothing. Market to Book is the market to book ratio, measured by market value of common equity divided by book value of equity. Current Returns is current year's market returns. Past Returns is last year's market returns. Current ROA is return on assets, measured as income before extraordinary items divided by total assets of current year. Tenure is the number of years that a CEO has held the CEO position. Age Dummy is set to 1 if an age value is reported on ExecuComp, and 0 otherwise. Age is a CEO's age. R\&D Dummy is set to 1 if a $R \& D$ value is reported on Compustat, and 0 otherwise. $R \& \boldsymbol{D}$ is measured as research and development expenses divided by sales. Advertising Dummy is set to 1 if an advertising value is reported on Compustat, and 0 otherwise. Advertising is measured as advertising expenses divided by sales. Continuous variables are ranked by deciles and divided by 10 for comparability with the InfoEnv_Index. $* * * * * * *$ indicates significance at the $0.01,0.05$, and 0.10 levels, respectively (two-tailed). 
Table 5

\section{Impact of Managerial Equity Incentives on the Relation between Information Environment and Managerial Ability}

\begin{tabular}{|c|c|c|c|}
\hline $\begin{array}{l}\text { Dependent } \\
\text { Variables }\end{array}$ & $\begin{array}{c}\text { Predicted } \\
\text { Sign }\end{array}$ & InfoEnv_Index & InfoEnv_Index \\
\hline DEA Score & & $\begin{array}{c}0.059 * * * \\
{[12.56]}\end{array}$ & $\begin{array}{c}0.053 * * * \\
{[11.02]}\end{array}$ \\
\hline DEA Score * Ownership & & $\begin{array}{c}0.040 * * * \\
{[3.18]}\end{array}$ & \\
\hline Ownership & & $\begin{array}{l}-0.001 \\
{[-0.11]}\end{array}$ & \\
\hline DEA Score * Wealth & & & $\begin{array}{c}0.055 * * * \\
{[4.07]}\end{array}$ \\
\hline Wealth & & & $\begin{array}{l}0.002 \\
{[0.31]}\end{array}$ \\
\hline Size & + & $\begin{array}{c}0.477 * * * \\
{[45.20]}\end{array}$ & $\begin{array}{c}0.480 * * * \\
{[43.65]}\end{array}$ \\
\hline Risk & - & $\begin{array}{l}-0.006 \\
{[-1.12]}\end{array}$ & $\begin{array}{l}-0.007 \\
{[-1.17]}\end{array}$ \\
\hline Performance & + & $\begin{array}{c}0.115 * * * \\
{[27.27]}\end{array}$ & $\begin{array}{c}0.115 * * * \\
{[26.24]}\end{array}$ \\
\hline Firm Age & $?$ & $\begin{array}{c}-0.032 * * \\
{[-2.36]}\end{array}$ & $\begin{array}{c}-0.036^{* * *} \\
{[-2.59]}\end{array}$ \\
\hline Growth & $?$ & $\begin{array}{l}-0.030^{*} \\
{[-1.92]}\end{array}$ & $\begin{array}{c}-0.032 * * \\
{[-1.97]}\end{array}$ \\
\hline Leverage & - & $\begin{array}{c}-0.038 * * * \\
{[-7.39]}\end{array}$ & $\begin{array}{c}-0.040 * * * \\
{[-7.48]}\end{array}$ \\
\hline Disclose & + & $\begin{array}{c}0.018 * * * \\
{[7.65]}\end{array}$ & $\begin{array}{c}0.017 * * * \\
{[7.15]}\end{array}$ \\
\hline Accrual Quality & + & $\begin{array}{c}0.013 * * * \\
{[3.83]}\end{array}$ & $\begin{array}{c}0.013 * * * \\
{[3.93]}\end{array}$ \\
\hline Smoothing & + & $\begin{array}{c}0.015 * * * \\
{[4.02]}\end{array}$ & $\begin{array}{c}0.016 * * * \\
{[4.02]}\end{array}$ \\
\hline Constant & & $\begin{array}{c}0.536 * * * \\
{[88.95]}\end{array}$ & $\begin{array}{c}0.534 * * * \\
{[86.23]}\end{array}$ \\
\hline $\begin{array}{l}\text { Firm Fixed Effects } \\
\text { Year Fixed Effects }\end{array}$ & & $\begin{array}{l}\text { Yes } \\
\text { Yes }\end{array}$ & $\begin{array}{l}\text { Yes } \\
\text { Yes }\end{array}$ \\
\hline Observations & & 15,025 & 14,002 \\
\hline R-squared & & 0.820 & 0.822 \\
\hline
\end{tabular}

This Table assesses how the relation between managerial ability and information environment varies with equity incentives, proxied by CEO stock ownership and firm-related wealth. Ownership is the number of shares held by the CEO scaled by total shares outstanding. Wealth is the sum of estimated option value (unexercised exercisable and unexercisable options) and the value of stock shares owned excluding options, scaled by the value of total shares outstanding. InfoEnv_Index is a composite index of information environment, measured by ranking the four individual proxies for information environment (trading volume, bid-ask spread, analyst following, and analyst forecast errors) into deciles in which firms with the highest information environment have a value of 10 . The four rankings are then summed and divided by 40 (total possible points), yielding a measure that ranges between 1 (highest 
information environment quality) and 0.1 (lowest information environment quality). DEA Score is our proxy for managerial ability and is based on the measure developed in Demerjian et al. (2012). Size is firm size, measured using total assets (in \$million). Risk is the standard deviation of monthly stock returns for the previous 36 months. Performance is return on assets, measured as income before extraordinary items divided by average total assets from the prior year. Firm Age is the number of years since the firm was first listed on CRSP. Growth is firm growth opportunities, measured as research and development expenses divided by total assets (R\&D Expenses / total assets). Leverage is firm leverage, measured as total long-term debt divided by total assets. Disclose is a dummy variable of management forecast likelihood set equal to 1 if there is an annual management earnings forecast in year t, 0 otherwise, following Baik et al. (2011). Accrual Quality is measured using a modified Dechow and Dichev (2002) accrual model, following Demerjian et al. (2013). For easier interpretation, Accrual Quality is multiplied by negative one to indicate that a high number indicates high accrual quality. Smoothing is income smoothing measured by the standard deviation of earnings divided by the standard deviation of cash flows from operations, where earnings and cash flows are scaled by lagged total assets following Baik et al (2017). For easier interpretation, Smoothing is multiplied by negative one to indicate that a high number indicates high smoothing. For easier interpretation, Smoothing is multiplied by negative one to indicate that a high number indicates high smoothing. Continuous variables are ranked by deciles and divided by 10 for comparability with the InfoEnv_Index. $* * * * * *$ indicates significance at the $0.01,0.05$, and 0.10 levels, respectively (two-tailed). 
Table 6

Impact of Monitoring on the Relation between

Information Environment and Managerial Ability

\begin{tabular}{|c|c|c|c|}
\hline $\begin{array}{l}\text { Dependent } \\
\text { Variables }\end{array}$ & $\begin{array}{l}\text { Predicted } \\
\text { Sign }\end{array}$ & InfoEnv_Index & InfoEnv_Index \\
\hline DEA Score & & $\begin{array}{c}0.055 * * * \\
{[11.87]}\end{array}$ & $\begin{array}{c}0.059 * * * \\
{[11.09]}\end{array}$ \\
\hline DEA Score * & & $-0.027 * *$ & \\
\hline Dedicated Institutional Ownership & & {$[-2.27]$} & \\
\hline Dedicated Institutional Ownership & & $\begin{array}{l}0.001 \\
{[0.20]}\end{array}$ & \\
\hline DEA Score * Independent Director\% & & & $\begin{array}{c}-0.029 * * \\
{[-2.15]}\end{array}$ \\
\hline Independent Director\% & & & $\begin{array}{l}0.011^{*} \\
{[1.95]}\end{array}$ \\
\hline Size & + & $\begin{array}{c}0.477 * * * \\
{[45.19]}\end{array}$ & $\begin{array}{c}0.412 * * * \\
{[31.28]}\end{array}$ \\
\hline Risk & - & $\begin{array}{l}-0.006 \\
{[-1.08]}\end{array}$ & $\begin{array}{l}0.000 \\
{[0.03]}\end{array}$ \\
\hline Performance & + & $\begin{array}{c}0.115 * * * \\
{[27.30]}\end{array}$ & $\begin{array}{c}0.097 * * * \\
{[20.08]}\end{array}$ \\
\hline Firm Age & $?$ & $\begin{array}{c}-0.033 * * \\
{[-2.44]}\end{array}$ & $\begin{array}{c}-0.060 * * * \\
{[-3.41]}\end{array}$ \\
\hline Growth & $?$ & $\begin{array}{l}-0.030^{*} \\
{[-1.94]}\end{array}$ & $\begin{array}{l}-0.026 \\
{[-1.44]}\end{array}$ \\
\hline Leverage & - & $\begin{array}{c}-0.038 * * * \\
{[-7.40]}\end{array}$ & $\begin{array}{c}-0.030 * * * \\
{[-5.10]}\end{array}$ \\
\hline Disclose & + & $\begin{array}{c}0.018 * * * \\
{[7.71]}\end{array}$ & $\begin{array}{c}0.016 * * * \\
{[6.41]}\end{array}$ \\
\hline Accrual Quality & + & $\begin{array}{c}0.013 * * * \\
{[3.86]}\end{array}$ & $\begin{array}{c}0.013 * * * \\
{[3.73]}\end{array}$ \\
\hline Smoothing & + & $\begin{array}{c}0.015 * * * \\
{[4.08]}\end{array}$ & $\begin{array}{c}0.011 * * * \\
{[2.59]}\end{array}$ \\
\hline Constant & & $\begin{array}{c}0.537 * * * \\
{[88.91]}\end{array}$ & $\begin{array}{l}0.656 * * * \\
{[153.67]}\end{array}$ \\
\hline $\begin{array}{l}\text { Firm Fixed Effects } \\
\text { Year Fixed Effects }\end{array}$ & & $\begin{array}{l}\text { Yes } \\
\text { Yes }\end{array}$ & $\begin{array}{l}\text { Yes } \\
\text { Yes }\end{array}$ \\
\hline Observations & & 15,027 & 11,356 \\
\hline R-squared & & 0.820 & 0.839 \\
\hline
\end{tabular}

This Table assesses how the relation between managerial ability and information environment varies with firms' monitoring, proxied by institutional ownership and independent director composition. Dedicated Institutional Ownership is the percentage of shares held by dedicated institutional investors (see Bushee (1998) for details on the categorization of institutional ownership), divided by shares outstanding. Independent Director\% is the percentage of the board of directors that is comprised of members who have no affiliation with the firm except as a director. InfoEnv_Index is a composite index of information environment, measured by ranking the four individual proxies for information environment (trading volume, bid-ask spread, analyst following, and analyst forecast errors) into deciles in which firms with the highest information environment have a value of 10 . The four 
rankings are then summed and divided by 40 (total possible points), yielding a measure that ranges between 1 (highest information environment quality) and 0.1 (lowest information environment quality). DEA Score is our proxy for managerial ability and is based on the measure developed in Demerjian et al. (2012). Size is firm size, measured using total assets (in \$million). Risk is the standard deviation of monthly stock returns for the previous 36 months. Performance is return on assets, measured as income before extraordinary items divided by average total assets from the prior year. Firm Age is the number of years since the firm was first listed on CRSP. Growth is firm growth opportunities, measured as research and development expenses divided by total assets (R\&D Expenses / total assets). Leverage is firm leverage, measured as total long-term debt divided by total assets. Disclose is a dummy variable of management forecast likelihood set equal to 1 if there is an annual management earnings forecast in year t, 0 otherwise, following Baik et al. (2011). Accrual Quality is measured using a modified Dechow and Dichev (2002) accrual model, following Demerjian et al. (2013). For easier interpretation, Accrual Quality is multiplied by negative one to indicate that a high number indicates high accrual quality. Smoothing is income smoothing measured by the standard deviation of earnings divided by the standard deviation of cash flows from operations, where earnings and cash flows are scaled by lagged total assets following Baik et al (2017). For easier interpretation, Smoothing is multiplied by negative one to indicate that a high number indicates high smoothing. Continuous variables are ranked by deciles and divided by 10 for comparability with the InfoEnv_Index. $* * * * *, *$ indicates significance at the $0.01,0.05$, and 0.10 levels, respectively (two-tailed). 